\title{
Utilization of Industrial Waste as Soil Stabilizer to Enhance Direct Shear Strength
}

\author{
Anita Setyowati Srie Gunarti ${ }^{1, *}$ Irwan Raharja ${ }^{2}$
}

\author{
${ }^{1}$ Department of Civil Engineering, Universitas Islam 45, Jl. Cut Meutia No. 83, Bekasi, West Java, Indonesia \\ ${ }^{2}$ Department of Accounting Information Systems, Universitas Bina Sarana Informatika, Jl. Banten No. 1, \\ Karangpawitan, Karawang Barat, West Java, Indonesia \\ *Corresponding author. Email: anita_ft@unismabekasi.ac.id
}

\begin{abstract}
A problem that often occurs in industrial areas is roads damage that are caused by the low carrying capacity of their subgrade as well as by over capacity of heavy vehicles passing through those roads. A lot of waste that is produced in industrial areas, which also another problem, can be used as soil stabilizers. This study proposed a method using industrial waste as stabilization material to improve the carrying capacity of the soil. Testing materials are prepared for both original and stabilized soil using three types of industrial waste, namely Silica Sand waste, and Dust Sand Foundry. One of mechanical property tests, i.e., direct shear test, was conducted with different percentage of waste for each sample. Result showed that there was $36.8 \%$ increase in the internal shear angle of the modified soil with $2.5 \%$ Dust Sand Foundry additives without the addition of Silica sand waste compared to the internal shear angle of the original soil.
\end{abstract}

Keywords: Industrial Waste, Direct Shear, Clay, Dust Sand Foundry, Silica Sand.

\section{INTRODUCTION}

Nowadays, industrial waste management is a challenge for every company that produces waste, in particular the specific waste. A special rule is needed to handle the waste (e.g., Dust Sand Foundry waste and Silica Sand waste). So far, such wastes have been widely used as materials for making brick [1]. However, the brick-making process using these two types of waste needs a long process. Therefore, it is necessary to treat this waste in a concise and easy way. This paper describes the feasibility study of utilizing two industrial wastes, namely Dust Sand Foundry (DSF) and Silica Sand waste (SS) as a soil additive construction material through laboratory experiments.

The effect of adding Dust Sand Foundry and Silica Sand waste to the Direct Shear strength of the clay soil will be discussed in this study. Previous studies on clay soil stabilization using Dust Sand Foundry and Silica sand waste have been carried out [2]-[5]. The results showed that there was a significant soil improvement on the California Bearing Ratio, Unconfined Compressive Strength and Triaxial Value. Research [6] on the use of two industrial wastes, namely heavy clay waste and Foundry Sand Blends as construction materials reported an increase in friction angle through direct shear test. This research used two types of waste with a special compound as a soil stabilizer mix to replace lime. The purpose of this study was to find the best composition of the waste mixture based on the highest Direct Shear Strength value, and to find the value of the improvement that occurred. This research focuses on the Direct Shear Strength Value without discussing the changes in chemical structure that occur. The research contributes to method of combining two types of waste, i.e., Silica Sand waste and Dust Sand Foundry which have benefit to each other in a particular mixture in regard to the highest Direct Shear Strength Value. The impact of this research is the innovation of an additives-stabilizer combination from industrial waste to improve soil carrying capacity. Therefore, it can provide technical and economic benefits.

\section{METHOD}

For laboratory experiment, some percentages of waste were needed, namely $2.5 \%$ of Silica Sand waste with $5 \%$ of the dry soil weight, and $2.5 \%$ of Dust Sand Foundry waste with $5 \%$ of the dry weight of the soil. Direct Shear testing was carried out on soil with Optimum Moisture Content (OMC) conditions. In this 
study, the clay type gathered at a depth of $20-50 \mathrm{~cm}$ from the original soil surface in disturbed conditions was used. Air-dry clay is mixed with Silica Sand waste and Dust Sand Foundry wastes to form a homogeneous mixture before left it in a closed bag for three days at room temperature. The test object was made before direct shear test was done based on the ASTM D-3080-04 standard. This test was done in Maximum Dry Density and Optimum Moisture Content conditions following the results of the Proctor standard compaction test. Table 1 shows the variation in the mixture composition.

Table 1. Additive Composition

\begin{tabular}{ccc}
\hline Varian Number & $\begin{array}{c}\text { Additive } \\
\mathrm{SS}^{\mathrm{a}}(\%)\end{array}$ & $\mathrm{DSF}^{\mathrm{b}}(\%)$ \\
\hline $1^{\mathrm{c}}$ & 0 & 0 \\
2 & 0 & 2.5 \\
3 & 0 & 5 \\
4 & 2.5 & 0 \\
5 & 2.5 & 2.5 \\
6 & 2.5 & 5 \\
7 & 5 & 0 \\
8 & 5 & 2.5 \\
9 & 5 & 5 \\
\hline
\end{tabular}

a Silica Sand Waste

${ }^{\mathrm{b}}$ Dust Sand Foundry Waste

'Original Clay

\section{RESUlt AND DiscusSion}

The results show the laboratory test for each additive composition. Some finding will be discussed.

\subsection{Results}

Soil sample from Universitas Islam 45 Bekasi has a specific gravity value (Gs) of 2,510 and the type of this soil is the organic clay [7] - [8], based on [9] classification. The results of the direct shear test are in the form of cohesion (c) and internal friction angle (П) values. Table 2 shows Optimum Moisture Content results for all variants. The Optimum Moisture Content value of stabilized soil from the compaction test result tends to decrease to the Optimum Moisture Content value of the original clay. However, the change is not significant since it was only about $0.01 \%$ to $0.02 \%$ range.

Table 2. Direct Shear test Result

\begin{tabular}{|c|c|c|c|c|c|}
\hline \multirow[t]{2}{*}{ Variant Number } & \multicolumn{2}{|c|}{ Additive Composition } & \multirow[t]{2}{*}{$\begin{array}{c}\mathrm{OMC}^{\mathrm{c}} \\
(\%)\end{array}$} & \multicolumn{2}{|c|}{ Direct Shear } \\
\hline & $\mathrm{SS}^{\mathrm{a}} \quad(\%)$ & $\operatorname{DSF}^{b}(\%)$ & & $\mathrm{C}^{\mathrm{d}}\left(\mathrm{kg} / \mathrm{cm}^{2}\right)$ & $\left.\mathrm{le}^{\circ}{ }^{\circ}\right)$ \\
\hline 1 & 0 & 0 & 29.75 & 0.0565 & 19 \\
\hline 2 & 0 & 2.5 & 29.42 & 0.0566 & 26 \\
\hline 3 & 0 & 5 & 29.06 & 0.05 & 26 \\
\hline 4 & 2.5 & 0 & 29.2 & 0.032 & 23 \\
\hline 5 & 2.5 & 2.5 & 29.35 & 0.032 & 25 \\
\hline 6 & 2.5 & 5 & 29.3 & 0.041 & 23 \\
\hline 7 & 5 & 0 & 29.21 & 0.052 & 23 \\
\hline 8 & 5 & 2.5 & 29.2 & 0.052 & 22.5 \\
\hline 9 & 5 & 5 & 29.0 & 0.0515 & 20.5 \\
\hline
\end{tabular}

${ }^{\text {aSilica Sand Waste }}$

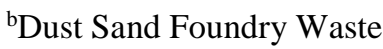

${ }^{c}$ Optimum Moisture Content

${ }^{\mathrm{d}}$ Cohesion

e Internal Friction Angle

\subsection{Discussion}

The cohesion value of soil mixed with $2.5 \%$ Dust Sand Foundry without Silica Sand waste experienced a less significant increase in Silica sand waste addition as shown in Figure 1. Soil mixtures with $2.5 \%$ Dust Sand Foundry showed the cohesion value (c) increase for $2.5 \%$ Silica Sand waste mixture, but the cohesion value decreased for $5 \%$ Silica Sand waste mixture compared to the cohesion value of the original soil because more
Silica Sand waste content causes less bonding/bonding between grains due to the chemical bonding process [10].

As an information, the cohesion value of the original soil is $0.565 \mathrm{~kg} / \mathrm{cm}^{2}$. The highest cohesion value $(0.566$ $\mathrm{kg} / \mathrm{cm}^{2}$ ) was found in the composition of the soil mixture of $2.5 \%$ Dust Sand Foundry without Silica Sand waste. This means that the cohesion value has increased by $0.18 \%$ from the cohesion value of the original clay soil. There was no cohesion value increase compared to the of the original soil for other variants. Figure 2 is a graph of the cohesion value to the percentage addition of Silica 
Sand waste. The cohesion value (Fig.2) shows a large decrease in the $2.5 \%$ Silica Sand waste grade against the cohesion value of the original soil.

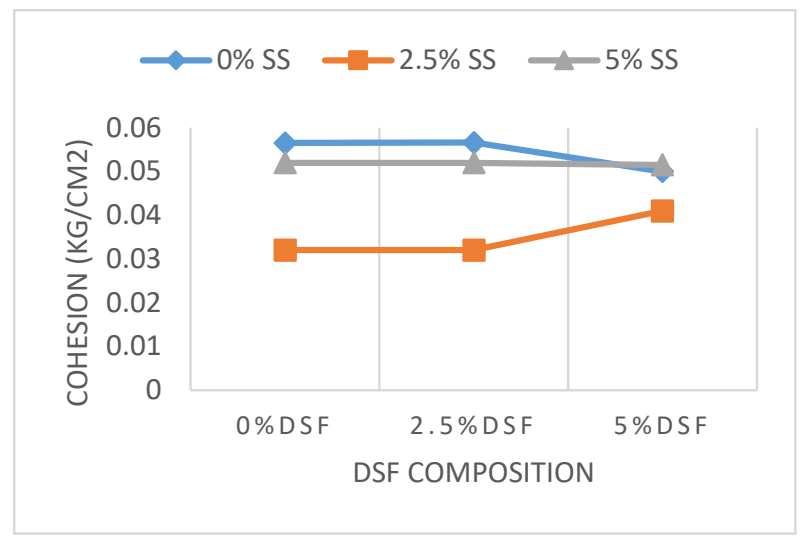

Figure 1 Cohesion values based on dust sand foundry addition

Small or large amount of silica sand waste in clay soil causes the soil mixture to lose cohesion so that the cohesion value in the direct shear test is smaller than the original soil cohesion value. Likewise, the large amount of dust sand foundry on clay soils (i.e. 5\%) causes the cohesion value to decrease from the original soil cohesion value in the direct shear test.

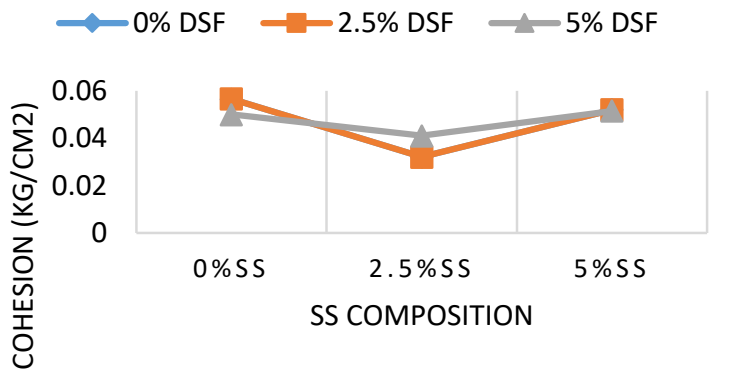

Figure 2 Cohesion values based on silica sand waste addition

Soil without Silica Sand waste mixture showed an increase of the internal friction angle (П) value for $2.5 \%$ and 5\% Dust Sand Foundry (36.84\% increase compared to the original soil $\Pi$ value as shown in Figure 3 ). It means the presence of Dust Sand Foundry waste is required but limited to the range composition from $2.5 \%$ to $5 \%$. In other variants, the internal friction angle (П) value was decrease as the percentage of Silica sand waste content increased compared to the original soil $\Pi$ value (Figure 4). This explains that Silica Sand waste does not have a good effect on the $\Pi$ value. The addition of Silica Sand waste to the original soil causes a reduction in soil density as seen from a decreasing $\Pi$ value. Soil without Silica Sand waste with the right Dust Sand Foundry measurement, shows that the $\Pi$ value of the soil is getting better. Judging from the highest $\mathrm{c}$ and $\Pi$ values, it was found that the best waste composition was the original soil mixed with 2.5\% Dust Sand Foundry without Silica Sand waste. Figure 3 shows ) values for the addition of dust sand foundry levels and Figure 4 shows ) values for the addition of silica sand waste levels.

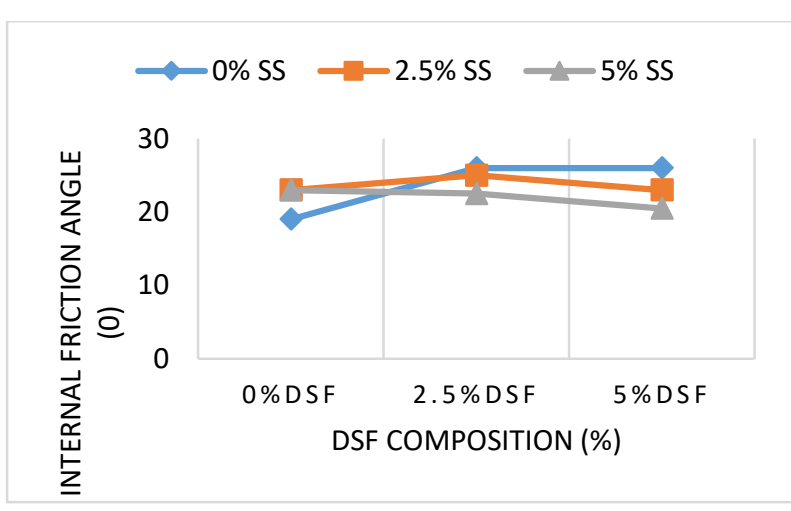

Figure 3 ) values for the addition of dust sand foundry levels

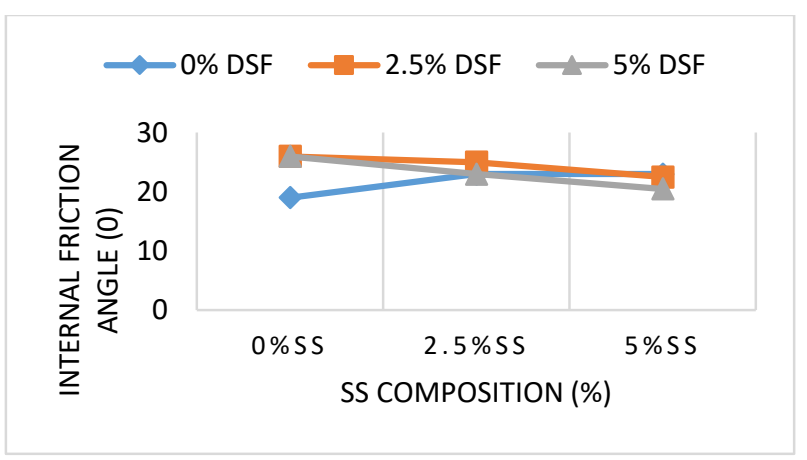

Figure 4 values for the addition of silica sand waste levels

\section{Conclusion}

The cohesion (c) and the internal friction angle (П) values on stabilized soil were improved by $0.18 \%$ and $36.84 \%$ compared to the cohesion and $\Pi$ values of the original soil for the original soil variants that used $2.5 \%$ Dust Sand Foundry (from the dry weight of the original soil). This shows that Dust Sand Foundry waste as a clay stabilizer additive was able to increase the shear strength of the original soil. Therefore, it provides some benefits for the industry (technical and economic). For the next research, the changes in the chemical properties of clay soils which are stabilized using lesser grade Silica Sand waste and fixed grade Dust Sand Foundry will be conducted, including the environmental feasibility testing. Other tests are needed such as the California bearing ratio test and the unconfined compressive strength test to complete this research. Micro analysis on stabilized soil needs to be done to be able to measure changes in soil minerals that occur during the stabilization process. 


\section{ACKNOWLEDGMENT}

The authors would like to thank to DRPM of Ministry of Research and Technology/BRIN for funding Applied Research Grant Program in 2019 No. T/140/E3/RA.00/2019 and No. 226/SP2H/LT/DRPM/2019.

\section{REFERENCES}

[1] C. C. Santos, L. V. O. Dalla Valentina, F. C. Cuzinsky, and L. C. Witsmiszyn, "Interlocking concrete paving blocks produced with foundry sand waste," in Materials Science Forum, 2018, vol. 912 MSF.

[2] A. S. Srie Gunarti, S. Samsiana, and I. Raharja, "Dry Dust Collector and Ceramic Silica Sand Waste as Clays Stabilizer," J. Comput. Theor. Nanosci., vol. 17, no. 2, 2020.

[3] A. S. S. Gunarti and I. Raharja, "Mechanical Properties Improvement of Clays Using Silica Sand Waste and Dust Sand Foundry Waste," in IOP Conference Series: Materials Science and Engineering, 2020, vol. 856, no. 1.

[4] A. S. S. Gunarti, S. Nuryati, P. A. Muttaqin, and I. Raharja, "Unconfined compression strength of soil using silica sand waste and dust sand foundry as a stabilizer," in Journal of Physics: Conference Series, 2020, vol. 1517, no. 1.
[5] A. S. S. Gunarti, S. Nuryati, F. Primatama, and I. Raharja, "Mechanical properties improvement of clay soils using dry dust collector and silica sand wastes,” IOP Conf. Ser. Mater. Sci. Eng., vol. 933, no. $1,2020$.

[6] Q. Dong, V. Huang, and B. Huang, "Laboratory Evaluation of Utilizing Waste Heavy Clay and Foundry Sand Blends as Construction Materials," J. Mater. Civ. Eng., vol. 26, no. 9, 2014.

[7] N. Kholis, A. Setyowati, S. Gunarti, and R. Sylviana, "STABILISASI TANAH LEMPUNG MENGGUNAKAN SEMEN DAN RENOLITH CLAY SOIL STABILIZATION USING CEMENT AND RENOLITH menyampurkan beberapa bahan tambah berupa bahan kimia. Salah satu upaya stabilisasi setelah tanah tersebut digunakan. Renolith merupakan bahan kim," vol. 6, no. 1, pp. 62-77.

[8] A. Gunarti, "Jurnal BENTANG Vol. 2 No. 1 Januari 2014," Daya Dukung Tanah Lempung Yang Distabilisasi Dengan Spent Catal. Rcc 15 Dan Kapur, vol. 2, no. 1, pp. 1-8, 2014.

[9] D. Panguriseng and U. M. Makassar, DASARDASAR, no. March. 2018.

[10] B. Ta'negonbadi and R. Noorzad, "Physical and geotechnical long-term properties of lignosulfonate-stabilized clay: An experimental investigation," Transp. Geotech., vol. 17, pp. 41$50,2018$. 